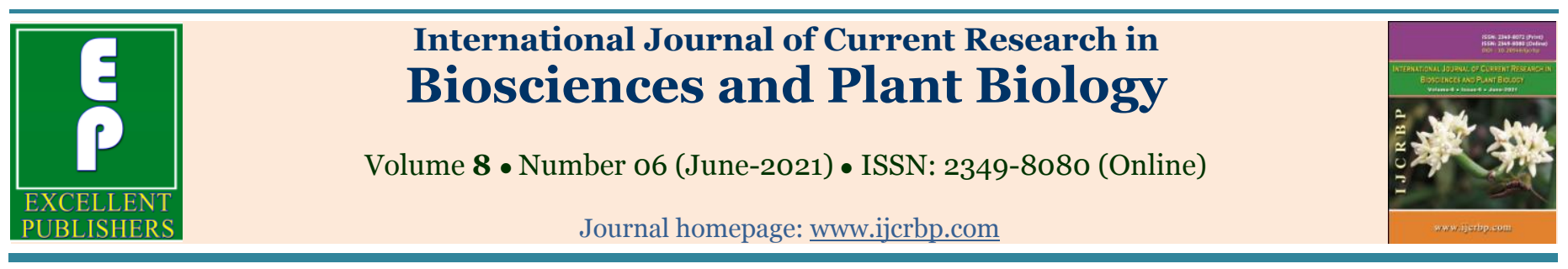

\title{
Polyploidy induction by colchicine treatment in garlic (Allium sativum L.), and effects of polyploidy on some traits
}

\section{Priyadarshini Pillai ${ }^{1} *$, Ameera Ahmed ${ }^{2}$, J. Ambika ${ }^{2}$, Aksab Sailas ${ }^{2}$, M. Anthima ${ }^{2}$, Asbana Parveen $^{2}$, G. N. Chaitrashree ${ }^{2}$, N. V. Hinduja ${ }^{2}$, Saba Farheen ${ }^{2}$}

${ }^{I}$ Assistant Professor and Head, Department of Botany, Jyoti Nivas College Autonomous, Bengaluru, Karnataka, India

${ }^{2}$ BSc Final Year (CBZ) Students, Department of Botany, Jyoti Nivas College Autonomous, Bengaluru, Karnataka, India

*Corresponding author; e-mail: priya.pillai07@gmail.com

\begin{tabular}{ll}
\hline Article Info & Abstract \\
\hline Keywords: & The garlic plant (Allium sativum L) is a suitable indicator plant for the determination of potential \\
Allium sativum $\mathrm{L}$. & genotoxic agents in the samples taken from the environment. Polyploidy has the utmost importance in \\
Chromosome & horticulture for the development of new varieties with desirable morphological traits referring to plant \\
Colchicine & size and vigor, leaf thickness, larger flowers with thicker petals, intense color of leaves and flowers, \\
Polyploidy & $\begin{array}{l}\text { long lasting flowers, compactness, dwarfness and restored fertility. Polyploidy may occur naturally } \\
\text { due to the formation of unreduced gametes or can be artificially induced by doubling the number of } \\
\text { stomata }\end{array}$ \\
& $\begin{array}{l}\text { chromosomes in somatic cells. Usually, natural polyploid plants are unavailable, so polyploidy is } \\
\text { induced synthetically with the help of mitotic inhibitors. Colchicine is a widely used mitotic inhibitor } \\
\text { for the induction of polyploidy in plants during their cell division by inhibiting the chromosome } \\
\text { segregation. The aim of this study was to determine the effect of various concentrations and duration } \\
\text { of colchicine treatment on root length, number of roots and stomatal densities Allium sativum L. }\end{array}$
\end{tabular}

- Received: 25 April 2021 • Revised: 30 May 2021 • Accepted: 02 June 2021 • Published Online: 06 June 2021

\section{Introduction}

Garlic (Allium sativum L.) is one of the most popular widely cultivated bulbous crop member of Alliaceae family and it's been consumed nearly by every person for various purposes. Garlic is one of high economical commodity of vegetables. Garlic is a diploid $(2 \mathrm{n}=2 \mathrm{x}=16)$ predominantly cross-fertilizing species. It is originated from the progenitor Allium longicuspis and its center of origin is Central Asia. Garlic has several medicinal properties such as antibacterial, antifungal, antiviral, antiprotozoal, antioxidant and anticancer properties. Mutation breeding is an important tool in crop improvement of vegetatively propagated crops, particularly in plants with reproductive sterility, where this is the only alternative. Irradiation of garlic cloves by physical and chemical mutagens is widely used to induce variability at the genetic level which alters number of biochemical processes leading to the desirable changes in the genotype. Although favorable cytological characteristics make species from the genus Allium attractive subjects for study, chromosome 
numbers are known for only about one-third of them and detailed cytological data are very limited (Ramesh, 2015). Significant changes to garlic breeding have occurred a long time ago. Garlic cultivars are rarely abundant nowadays, especially the local cultivars from farmers and domestic markets. The lack of interest from farmers to breed the local cultivars is due to its tiny bulbs and high costs compared to imported garlic. Garlic (Allium sativum L.) is one of the popular horticulture plant, known by people which have lots of benefits from its bulbs. Phytochemical constituents of its bulbs are commonly used as flavors and drug materials containing essential oils and organosulphures.

Polyploidy is one of the important tools to produce genetically superior plants. Polyploidy forms as a result of multiple sets of chromosomes in excess of the diploid number in plants. In breeding and genetic studies, reduction or increase all sets of chromosomes is a powerful mechanism for generating genetic variation and creation and changing genotypes (Wendel, 2000; Dhooghe et al. 2010; Omidbaigi et al. 2010; Dar et al. 2017).

Polyploids are organisms with three or more complete chromosome sets. Polyploidization is widespread in plants and animals, and is an important mechanism of speciation. The formation of fertile polyploids not only promoted the interflow of genetic materials among species and enriched the species diversity, but also laid the foundation for polyploidy breeding. The study of polyploids has both important theoretical significance and valuable applications. The production and application of polyploidy breeding have brought remarkable economic and social benefits. (Can, 2012).

Polyploidy is responsible for the creation of thousands of species in today's planet, and will continue to do so. It is also responsible for increasing genetic diversity and producing species showing an increase in size, vigour and an increased resistance to disease. Polyploidy is a prominent force of shaping the evolution of plants (Winge, 1917). Polyploids were successfully produced by treating plant parts with colchicine, colchicine, oryzalin, colcemid, trifluralin, amiprophosmethyl (APM) etc. Although colchicine remained the most used for induction of polyploidy. Chromosome doubling was achieved by different concentrations of colchicine (Kazi, 2015). This experiment aimed to establish an efficient procedure for colchicine concentrations effect in garlic and to determine optimum concentration and exposure time period identify certain morphological and Physiological traits.

\section{Materials and methods}

The study was conducted at the Department of Botany, Jyoti Nivas College (Autonomous), Bangalore. Material used in this study was garlic (Allium sativum L.) bulb obtained from the Madiwala market in Bangalore in January, 2021.

Chemicals: Colchicine, used in this study was of analytical grade, from reputed manufacturers.

Experimental design: Experimental design of this study used Randomized Factorial Block design with three replications and twenty combinations of treatments. The first factor was the concentration of colchicine: $0 \%$ (D0), $0.1 \%$ (D1), $0.2 \%$ (D2), and $0.3 \%$ (D3). The second factor was immersion time: 0 hours (T0), 6 (T1), 12 (T2), 18 (T3), and $24 \mathrm{~h}$ (T4). The study was conducted under following stages: Seeds were prepared from mature seeds and dried under sunlight for $2 \mathrm{~d}$. The seeds were treated with colchicine for certain durations. Planting medium were prepared by mixing soil and plotted using $1 \times 4 \mathrm{~m}$ plastic mulches. Plots were arranged in proper distances. Weeding was done manually and periodically every two weeks. Observable parameters in this study were root lengths, number of roots, stomatal density and chromosomes.

The squash technique for described by Al-Sabti and Kurelec (1985) and Al-Sabti (1989) was used for the preparation of chromosomes in Garlic root tips. Cells with chromosomes at different stages of mitosis were examined under the compound microscope and photomicrographs taken at a magnification of $\times 100$. The prophase, metaphase, anaphase and telophase stages are examined to study chromosome behavior. Stomatal density and number of stomata was analyzed using replica method, i.e. Leaf samples were cleaned and smeared with clear nail coloring. The smears were left to dry in ambient condition for 5 min. The smear was taped using clear tape and flattened. The tapes were released gently, and then placed on to object glass. Observation of stomatal density was done using a digital microscope (Zeiss Primo Star) with 100x magnification. The data obtained were analyzed by ANOVA with significant level of $5 \%$ followed by Duncan's new Multiple Range Test. 


\section{Results and discussion}

Chromosome number and karyotype of Allium sativum has $16(2 n=16)$ there are four pairs of metacentric, three pairs of submetacentric and one pair sub telocentric chromosomes. The sixth pair of sub telocentric chromosomes was nucleolar represented by prominent satellites. The karyotypic formula was $8 \mathrm{M}+6 \mathrm{Sm}+2 \mathrm{St}$. The meristematic region of garlic roots without colchicine treatment, used as control shows a normal mitotic distribution. Most of the actively dividing cells were in prophase and few in metaphase, anaphase and telophase stages of cell division. The metaphase chromosomes were lined up at the equator and were pulled evenly towards spindle poles for the cells at anaphase. No abnormal chromosome was observed. Abnormalities in a metaphase stage were observed with increased concentration of colchicine. Many cells had abnormal mitotic organization with chromosomes being pulled unevenly at a concentration of $0.5 \%$ colchicine treated for $24 \mathrm{~h}$. Some cells exhibited C-metaphase with condensed chromosomes arrested in their prometaphase stage for the same treatment.

Finnie and Vanstaden (1991) reported colchicine levels in Gloriosa superba corms to the level of around $0.9 \%$ (DM). Gloriosa species apparently would be a better source of commercial colchicine for Colchicum autumnale where the levels of colchicine around 0.2\% were reported (Bellet and Gaignault, 1985). Earlier study of Gloriosa superba revealed that colchicine levels are highest during the initial growth of plant and these levels decline during maturation, with a slight increase in alkaloid content when corms become dormant at the end of season (Thakur et al., 1975).

The growth of seedlings under the effect of colchicine was assessed a month after treatment. All of the control seedlings and the seedlings resulted from treatment with different concentrations of colchicine for $24 \mathrm{~h}$, survived. Root length is the result of cellular extension in root system. The root meristem is able to perform continuous growth, not limited to cell enlargement. The result of colchicine treatment to root length is presented in Table 1. The results of statistical analysis showed that interaction between the concentration and immersion time of colchicine did not have a significant effect on the root length of Allium sativum. However, the concentration level of colchicine had a significant effect on the root length equal to $9.31 \mathrm{~cm}$ in the control treatment (D0) (Table 1). The longest root length is shown in the treatment without colchicine with immersion time of $18 \mathrm{~h}$ (D0T3), with length of $9.74 \mathrm{~cm}$. Treatment of $0.3 \%$ colchicine with $12 \mathrm{~h}$ immersion time (D3T2) showed the shortest root length $(5.17 \mathrm{~cm})$, although not significantly different $(\mathrm{F}=1.358, \mathrm{P}>0.05)$ with control (D0T0). The results may indicate that colchicine treatment did not affect significantly to root length. In addition, it is suspected that colchicine causes an increase in ethylene content. Ethylene is a hormone that stimulates the acceleration of cell elongation and cell division. Ethylene does not stimulate growth directly but through the action of gibberellin. Ethylene itself may inhibit the auxin and cytokinin (Rohma dan Saputro, 2016). Colchicine administration with specific concentrations has an effect on decreasing root length, due to disruption of cell division that hinders plant growth. Zingiber officinale Rosc. treated with colchicine also did not exhibit any significant difference in root length (Ariyanto et al., 2011). In contrary, other study reported that $0.1 \%$ colchicine treatment may increase root length significantly than control in Gerbera jamesonii Bolus cv. Sciella.

Similar to previous results, colchicine treatment did not produce any significant effects to number of roots of Allium sativum. The results of statistical analysis showed that control treatment (D0) produced the highest number of roots while the lowest was produced in the treatment of $0.2 \%$ colchicine (D2) and not significantly different from the concentration treatment of 0.1 (D1) and $0.3 \%$ (D3) (Table 2). In similar trend to prior results, colchicine treatment produced lesser number of roots of Allium sativum $\mathrm{L}$ than control. Limiting the number of roots will affect plant's ability to absorb colchicine in an optimum capacity leading to a hindered growth due to cell division failure (Jadrná, Plavcová and Kobza, 2010). Earlier studies from colchicine treatments also revealed similar number of roots of Phalaenopsis pulcherrima, $P$. amabilis, and $P$. amboinensis (dan Hosnia, 2018; Rahayu et al., 2015).

The results of statistical analysis revealed that colchicine treatments produced a significant effect to stomatal density. The highest stomatal density was observed from $\mathrm{D}_{0} \mathrm{~T}_{3}$ with no significant difference to $\mathrm{D}_{0} \mathrm{~T}_{0}$ of stomata/ $/ \mathrm{mm}^{2}$. The lowest stomatal density was observed from $\mathrm{D}_{2} \mathrm{~T}_{3}$ with density of 11.58 stomata/ $\mathrm{mm}^{2}$. Similar result was also reported from $0.1 \%$ colchicine treatment with 8-h immersion time in Gerberra jamesonii Bolus cv. Sciella with density of 5.67 stomata/ $\mathrm{mm}^{2}$ compared to the control with density of 16.67 stomata $/ \mathrm{mm}^{2}$. In other 
study, $0.1 \%$ colchicine treatment with 24-h immersion time was able to reduce stomatal density of Gossypium arboreum to $6.50 \mathrm{stomata} / \mu \mathrm{m}^{2}$ compared to the control treatment (14.83 stomata/ $\mu \mathrm{m}^{2}$ ) (Yang et al., 2015). The colchicine effect to the number of stomata is presented in Table 4 and Fig. 1.

It is also observed that the interaction between colchicine concentration and immersion time had a significant effect $(\mathrm{F}=2.653, \mathrm{P}>0.05)$ on the number of stomata of Allium sativum. The highest number of stomata was observed from $\mathrm{D}_{0} \mathrm{~T}_{3}$, while the lowest number of stomata was observed from $\mathrm{D}_{2} \mathrm{~T}_{3}$ (Table 4). The results of statistical analysis revealed that colchicine concentration level had a significant effect $(\mathrm{F}$ $=6.069, \mathrm{P}>0.05)$ on the number of stomata. The highest number of stomata produced in the control treatment (D0) although not significantly different $(\mathrm{F}=$ $1.331, \mathrm{P}>0.05)$ with treatment $\mathrm{D}_{1}$ and $\mathrm{D}_{3}$. No significant differences were observed within immersion time to the number of stomata. In addition, $0.2 \%$ colchicine treatment produced the lowest number of stomata compared to the control treatment $\left(\mathrm{D}_{0} \mathrm{~T}_{0}\right)$. Similar result was also reported from colchicine treatment to Sorghum bicolor L. plants in which control produced a higher number of stomata than other treatments (Ardabili et al., 2015). A decrease in stomatal density may be caused by inappropriate colchicine concentration. Other evidence also showed that polyploid plants had a lower stomatal density than diploid plants because of enlarged size of stomata per leaf area (Yulianti et al., 2015; Yunus et al., 2018).

Table 1. Effect of colchicine on root length of Allium sativum L.

\begin{tabular}{lllllll}
\hline \multirow{2}{*}{ Colchicine concentration (\%) } & \multicolumn{2}{l}{ Duration (h) } & \multirow{2}{*}{ Mean (cm) } \\
\cline { 2 - 6 } & $\mathbf{0}(\mathbf{T 0})$ & $\mathbf{6}(\mathbf{T 1})$ & $\mathbf{1 2}(\mathbf{T} 2)$ & $\mathbf{1 8}(\mathbf{T 3})$ & $\mathbf{2 4}(\mathbf{T 4})$ & \\
\hline $0.0(\mathrm{D} 0)$ & $9.31^{\mathrm{a}}$ & $7.39^{\mathrm{a}}$ & $8.00^{\mathrm{a}}$ & $9.74^{\mathrm{a}}$ & $7.37^{\mathrm{a}}$ & $8.00^{\mathrm{b}}$ \\
0.1 (D1) & $9.50^{\mathrm{a}}$ & $6.32^{\mathrm{a}}$ & $6.22^{\mathrm{a}}$ & $8.30^{\mathrm{a}}$ & $5.31^{\mathrm{a}}$ & $7.48^{\mathrm{a}}$ \\
$0.2(\mathrm{D} 2)$ & $6.82^{\mathrm{a}}$ & $7.63^{\mathrm{a}}$ & $7.20^{\mathrm{a}}$ & $5.40^{\mathrm{a}}$ & $5.93^{\mathrm{a}}$ & $6.38^{\mathrm{a}}$ \\
0.3 (D3) & $8.09^{\mathrm{a}}$ & $5.20^{\mathrm{a}}$ & $5.17^{\mathrm{a}}$ & $7.79^{\mathrm{a}}$ & $5.60^{\mathrm{a}}$ & $6.17^{\mathrm{a}}$ \\
Mean (cm) & $8.36^{\mathrm{a}}$ & $6.24^{\mathrm{a}}$ & $3.62^{\mathrm{a}}$ & $7.67^{\mathrm{a}}$ & $5.98^{\mathrm{a}}$ & \\
\hline
\end{tabular}

Note: Similar letters are not significantly different based on Duncan's MRT $(\mathrm{P}>0.05)$.

Table 2. Effect of colchicine on number of roots of Allium sativum L.

\begin{tabular}{|c|c|c|c|c|c|c|}
\hline \multirow{2}{*}{ Colchicine concentration (\%) } & \multicolumn{5}{|c|}{ Duration (h) } & \multirow{2}{*}{ Mean (no.) } \\
\hline & 0 (T0) & 6 (T1) & $12(\mathrm{~T} 2)$ & 18 (T3) & 24 (T4) & \\
\hline 0.0 (D0) & $26.69^{a}$ & $27.31^{\mathrm{a}}$ & $29.00^{\mathrm{a}}$ & $34.00^{\mathrm{a}}$ & $30.00^{\mathrm{a}}$ & $31.43^{\mathrm{b}}$ \\
\hline 0.1 (D1) & $23.32^{\mathrm{a}}$ & $23.64^{\mathrm{a}}$ & $18.64^{\mathrm{a}}$ & $23.00^{\mathrm{a}}$ & $23.45^{\mathrm{a}}$ & $23.07^{\mathrm{a}}$ \\
\hline $0.2(\mathrm{D} 2)$ & $20.65^{a}$ & $19.88^{\mathrm{a}}$ & $25.00^{\mathrm{a}}$ & $22.77^{\mathrm{a}}$ & $25.30^{\mathrm{a}}$ & $22.67^{\mathrm{a}}$ \\
\hline $0.3(\mathrm{D} 3)$ & $32.30^{\mathrm{a}}$ & $17.00^{\mathrm{a}}$ & $21.29^{\mathrm{a}}$ & $25.88^{\mathrm{a}}$ & $19.33^{\mathrm{a}}$ & $23.10^{\mathrm{a}}$ \\
\hline Mean (no.) & $28.52^{\mathrm{a}}$ & $23.24^{\mathrm{a}}$ & $22.50^{\mathrm{a}}$ & $26.31^{\mathrm{a}}$ & $23.36^{\mathrm{a}}$ & \\
\hline
\end{tabular}

Note: Similar letters are not significantly different based on Duncan's MRT $(\mathrm{P}>0.05)$.

Table 3. Effect of colchicine on stomatal density of Allium sativum L.

\begin{tabular}{|c|c|c|c|c|c|c|}
\hline \multirow{2}{*}{ Colchicine concentration (\%) } & \multicolumn{5}{|c|}{ Duration (h) } & \multirow{2}{*}{$\begin{array}{l}\text { Mean } \\
\left(\text { Stomata } / \mathrm{mm}^{2}\right)\end{array}$} \\
\hline & 0 (T0) & $6(\mathrm{T1})$ & 12 (T2) & 18 (T3) & 24 (T4) & \\
\hline $0.0(\mathrm{D} 0)$ & $22.13^{\text {def }}$ & $18.77^{\text {bcde }}$ & $29.00^{\mathrm{a}}$ & $24.12^{\mathrm{f}}$ & $18.23^{\text {bcde }}$ & $20.16^{\mathrm{b}}$ \\
\hline $0.2(\mathrm{D} 2)$ & $14.29^{\mathrm{abc}}$ & $22.63^{\mathrm{ef}}$ & $15.22^{\mathrm{abcd}}$ & $11.58^{\mathrm{a}}$ & $12.62^{\mathrm{ab}}$ & $16.35^{\mathrm{a}}$ \\
\hline $0.3(\mathrm{D} 3)$ & $18.79^{\text {bcde }}$ & $19.03^{\text {bcde }}$ & $21.54^{\mathrm{a}}$ & $21.78^{\text {def }}$ & $19.49^{\text {cdef }}$ & $20.22^{\mathrm{b}}$ \\
\hline
\end{tabular}

Note: Similar letters are not significantly different based on Duncan's MRT $(\mathrm{P}>0.05)$. 
Table 4. Effect of colchicine on number of stomata of Allium sativum L.

\begin{tabular}{|c|c|c|c|c|c|c|}
\hline \multirow{2}{*}{ Colchicine concentration $(\%)$} & \multicolumn{5}{|c|}{ Duration (h) } & \multirow{2}{*}{ Mean (no.) } \\
\hline & 0 (T0) & 6 (T1) & 12 (T2) & 18 (T3) & 24 (T4) & \\
\hline $0.0(\mathrm{D} 0)$ & $413.26^{\mathrm{def}}$ & $367.00^{\text {bcde }}$ & $357.00^{\text {abcde }}$ & $502.31^{f}$ & $374.00^{\text {bcde }}$ & $408.14^{b}$ \\
\hline 0.1 (D1) & $365.30^{\text {bcde }}$ & $351.62^{\text {bcde }}$ & $352.00^{\text {bcde }}$ & $380.00^{\text {cdef }}$ & $401.62^{\text {cdef }}$ & $378.30^{\mathrm{b}}$ \\
\hline 0.2 (D2) & $289.00^{\mathrm{abc}}$ & $462.30^{\mathrm{ef}}$ & $303.64^{\text {abcd }}$ & $242.67^{\mathrm{a}}$ & $266.00^{\mathrm{ab}}$ & $309.730^{\mathrm{a}}$ \\
\hline 0.3 (D3) & $365.00^{\text {bcde }}$ & $378.67^{\text {bcde }}$ & $362.00^{\text {bcde }}$ & $439.33^{\mathrm{def}}$ & $389.03^{\text {cdef }}$ & $386.89^{\mathrm{b}}$ \\
\hline Mean (no.) & $358.18^{\mathrm{a}}$ & $383.41^{\mathrm{a}}$ & $355.76^{\mathrm{a}}$ & $391.54^{\mathrm{a}}$ & $355.29^{\mathrm{a}}$ & \\
\hline
\end{tabular}

Note: Similar letters are not significantly different based on Duncan's MRT $(\mathrm{P}>0.05)$.

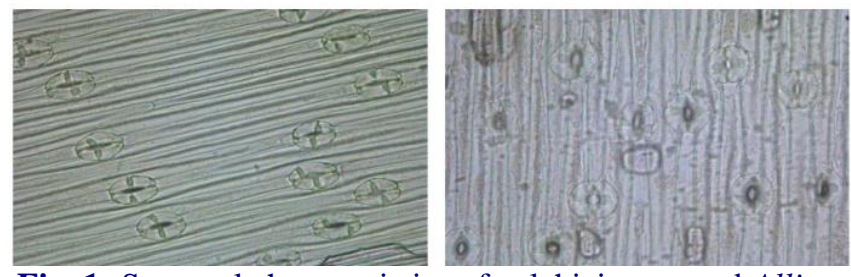

Fig. 1: Stomatal characteristics of colchicine treated Allium sativum $\mathrm{L}$.

\section{Conclusions}

Colchicine treatment showed a variety of results in which no parameters were significantly affected by the treatments regarding improvement of physiological parameters. Growth of garlic (Allium sativum L.) is delayed due to higher colchicine concentration and longer immersion durations. The $0 \%$ colchicine treatment for $12 \mathrm{~h}$ affected significantly on root length, number of roots, stomatal density, number of stomata and inhibition of mitotic metaphase in each treatment. Polyploidization plays a key role in plant breeding and crop improvement. Polyploid garlic plants possess lower stomatal density, thicker leaves, higher chloroplast number, higher secondary metabolites, and slower root and shoot formation compared to diploid plants. Polyploids have a thicker cell size but have a low cell number per leaf blade as compared to the diploids. The genetic diversity in garlic as a result of colchicine treatment aids to know the different characters of genes, so that it can be used for the finding of superior cultivars in garlic varieties.

\section{Conflict of interest statement}

Authors declare that they have no conflict of interest.

\section{References}

Ardabili, G. S., Zakaria, R. A., Zare, N., 2015. In vitro induction of polyploidy in Sorgum bicolor L. Cytologia, 8-(4): 495-503.
Ariyanto, S. E., Parjanto, Supriyadi, 2011. Pengaruh Kolkisin Terhadap Fenotip Dan Jumlah Kromosom Jahe (Zingiber officinale Rosc.). Sains dan Teknologi 4(1), 1-15.

Basu, R. K., 1977. Effects of X-rays and colchicine on pollen of Trichosanthesanguina L. (Cucurbitaceae). Grana, 16(2): 105-109.

Brankovic, S., Radenkovic, M., Velkovic, S., Ivetic, V., Pavlovic, D., Miladinovic, B., 2011. Comparison of the hypotensive and bradycardiac activity of Ginkgo, garlic, and onion extract. Clin. Exp. Hypertens., 33(2): 95-99.

Cerella, C., Dicato, M., Jacob, G., Diederich, M., 2011. Chemical properties and mechanisms determining the anti-cancer action of garlic-derived organic sulfur compounds. Anticancer Agents Med. Chem., 11(3): 267-271.

Finnie, J. F., van Staden, J., 1991. Isolation of colchicine from Sandersonia aurantica and Gloriosa superba variation in the alkaloid levels of plant grown in vivo. J. Plant Physiol., 138: 691-695.

Gantait, S., Mandal, N., Bhattacharyya, S., Das, P. K., 2011. Induction and identification of tetraploids using in vitro colchicine treatment of Gerbera jamesonii Bolus cv. Sciella. Plant Cell, Tissue Organ Cult., 106: 485-493.

Ginter, E., Simko, V., 2010. Garlic (Allium sativum L.) and cardiovascular diseases. Brastisl Lek Listy, 111(8): 452-456.

Jadrná, P., Plavcová, O., Kobza, F., 2010. Morphological changes in colchicine-treated Pelargonium $\times$ Hortorum L.H. Bailey greenhouse plants. Hortic. Sci. (Prague), 37(1): 27-33.

Kazi, N. A., 2015. Polyploidy in flower crops. Res. J. Interdiscipl. Sci., III/XVI: 2930-2936.

Prikhodko, N. I., 1974. Some economically valuable characters of polyploid cabbages. Trudy poPriklad noiBotanike, Genetiki-i-Selektsii, 51(3): 172-180.

Rahayu, E. M. D., Sukma, D., Syukur, M., 2015. Induksi Poliploidi Phalaenopsis amabilis (L.) Blume dan Phalaenopsis amboinensis J. J. Smith Dengan 
Kolkisin Dalam Kultur In Vitro. J. Agron. Indonesia, 43(3): 219-226.

Rohma, Saputro, 2016. Analisis Pertumbuhan Tanaman Kedelai (Glycine max L.) Varietas Grobogan pada Kondisi Cekaman Genangan. J. Sains dan Seni Its, 5(2): 29-33.

Soetopo, L., Hosnia, 2018. In vivo polyploid-induction by colchicine on orchids Phalaenopsis pulcherrima (Lindl.) J.J Smith. Biosci. Res., 15(2): 941-949.

Swardana, S. M., Gunadi, 2007. Potensi Pengembangan BAwang Putih (Allium sativum L.) Dataran Rendah Varietas Lokal Sanur. AgriTrop, 26(1): 1923.

Tang, Z. Q., Chen, D. L., Song, Z. J., He, Y. C., Cai, D. T., 2010. In vitro induction and identification of tetraploid plants of Paulownia tomentosa. Plant Cell Tissue Organ Cult., 102(2): 213-220.

Tavan, M., Mirjalili, M. H., Karimzadeh, G., 2015. In vitro polyploidy induction: Changes in morphological, anatomical, and phytochemical characteristics of Thymus persicus (Lamiaceae). Plant Cell Tiss Organ Cult., 122(3): 573-583.

Thakur, R.S., Potesilova, H., Santavy, F., 1975. Substances from plants of the subfamily Wumborcoidae and their derivatives Part LXXX alkaloids of the plant Gloriosa superba L. Planta Med., 28: 201-209.
Uguru, M. I., 2011. Evidence of polyploidy in fluted pumpkin (Telfairia occidentalis Hook F.). Afr. J. Plant Sci., 5(5): 287-290.

Vichiato, M. V. D. M., Vichiato, M., Pasqual, M., Rodrigues, F. A., Castro, D. M. D., 2014. Morphological effects of induced polyploidy in Dendrobium nobile Lindl. (Orchidaceae). Crop Breed. Appl. Biotechnol., 14: 154-159.

Wanjari, K.B., 1973. A colchicine induced sectorial chimera in bitter-gourd (Momordica charantia L.). Science and Culture, 39(10): 432-433.

Winge, O., 1917. The chromosomes, their number and general importance. C.R. Trav. Lab. Carlsberg, 13: 131-275.

Yang, N., Rong, E., Li, Q., Dong, J., Du, T., Zhao, X., $\mathrm{Wu}, \quad$ Y., 2015. Tetraploid induction and identification of Gossypium arboreum. Agricult. Sci., 6: 436-444.

Yulianti, F., Purwito, A., Husni, A., Dinarti, D., 2015. Induksi tetraploid tunas pucuk jeruk siam simadu (Citrus nobilis Lour.) menggunakan kolkisin secara in vitro. J. Agron., 43(1): 66-71.

Yunus A, Parjanto, Samanhudi, Hikam, M. P., Widyastuti, 2018. Polypliod response of Artemisa annua L. to colchicine treatment. IOP Conf. Series: Earth and Environ. Sci., 14: 1-7.

\section{How to cite this article:}

Priyadarshini, P., Ameera, A., Ambika, J., Sailas, A., Anthima, M., Parveen, A., Chaitrashree7, G. N., Hinduja, N. V., Farheen, S., 2021. Polyploidy induction by colchicine treatment in garlic (Allium sativum L.), and effects of polyploidy on some traits. Int. J. Curr. Res. Biosci. Plant Biol., 8(6): 23-28.

doi: https://doi.org/10.20546/ijcrbp.2021.806.002 